\title{
Effects of market liberalisation on smoking in Japan
}

\author{
Kaori Honjo, Ichiro Kawachi
}

\begin{abstract}
Objective-To document the effect of the liberalisation of the Japanese tobacco market on Japanese smoking rates and on Japanese tobacco industry practices.

Data source-Asahi Shimbun (major daily newspaper) from 1980 to 1996.

Study selection-Review of media coverage on the effects of market liberalisation following the imposition of the USA's section 301 trade sanction.

Data synthesis-The opening of Japan's tobacco market to foreign cigarette companies stalled a decline in smoking prevalence. Smoking rates among young women increased significantly, and also appear to be on the rise among adolescents. Aggressive marketing and promotional activities by US and Japanese tobacco companies in response to trade liberalisation appear responsible for these adverse trends. Steep increases in sales through vending machines were also possible contributors to the rising smoking prevalence among adolescents. On the positive side, market liberalisation indirectly promoted smoking control efforts in Japan, by causing an antismoking movement to coalesce.
\end{abstract}

Conclusion-Market liberalisation in Japan played a significant role in increasing smoking prevalence among young women and adolescents while helping to transform the issue of smoking in Japan from a matter of individual choice to a public health problem.

(Tobacco Control 2000;9:193-200)

Keywords: Japan; market liberalisation

The high prevalence of cigarette smoking is one of the most serious health problems in Japan. The prevalence of cigarette smoking among adult Japanese males (age 20 years and older) was $57.5 \%$ in 1996 , while that among adult Japanese females was $14.2 \%{ }^{1}$ The prevalence of cigarette smoking among Japanese males is the highest among developed countries. $^{2}$ The overall smoking rate has declined significantly since its highest point in the 1960s, but has stalled in the late 1980s. One possible reason for this stagnation was the opening of the Japanese market to foreign tobacco companies in 1987. We examine the effect of the liberalisation of the Japanese tobacco market on the Japanese tobacco industry and on Japanese society.
History of tobacco use in Japan

Cigarette smoking did not become popular among the Japanese general public until about 10 years after second world war, lagging 20-30 years behind its popularity in the US. ${ }^{3}$ However, the first use of tobacco in Japanese history dates from the 16th century, when Portuguese merchants brought tobacco to the southern part of Japan. Smoking spread from south to north, along with the cultivation of tobacco leaf. Cigarette manufacturing began around 1870 at the beginning of the Meiji era. At that time, a few large corporations gradually made cigarette smoking popular among the general population. ${ }^{4}$

The Meiji government created a government monopoly over tobacco at the end of the 19th century. A tax on tobacco was introduced for the first time in 1883. Then, in order to collect taxes more efficiently to fund the expansion of armaments during a series of wars, the government made leaf production and procurement a state monopoly with the Tobacco Leaf Monopoly Law in 1886. Since then, the Japanese government has been directly involved in promoting tobacco sales, with the result that cigarette smoking became popular. ${ }^{4}$

The Japanese government in the late 1890s created the Japan Public Monopoly Corporation (JPMC), which later became one of the largest tobacco companies in the world. In the early 1980s, the Japanese government began discussions on the privatisation of JPMC. Although strongly opposed by the JPMC union, the retailers association, the farmers association, and anti-smoking groups, the Japanese government in 1985 converted JPMC to Japan Tobacco, Inc (JT), a nongovernmental corporation, in order to enhance the corporation's economic growth. ${ }^{5-10}$ Pressure for market liberalisation from the US government influenced this decision. ${ }^{10}$ Beginning in 1978, the US government requested the Japanese government to decrease the tariff on US tobacco, and gradually pressured the Japanese government to open its market to US tobacco exports. The conversion of JPMC to JT was partly motivated by the Japanese government's belief that it was necessary to make JPMC competitive against the anticipated intrusion of US tobacco. A plan to break up JPMC into several corporations was resisted by JPMC ${ }^{11}$ and the government adopted a plan to keep tobacco a domestic monopoly.

\section{Market liberalisation}

The decline of the US domestic market was a critical factor in the efforts of US manufacturers 
Table 1 Brief summary of market liberalisation process in fapan

1978 First US government request for Japan to decrease tariff on US tobacco

1982 Tariff on imported tobacco reduced from $90 \%$ to $20 \%$

1985 Conversion from Japan Public Monopoly Corporation (JPMC) to Japan Tobacco Inc (JT)

Monopoly in sales and distribution ended

Budgetary ratio concept in advertising abolished in favour of restriction in the total

volume of radio, televison, and print advertising.

1987

Tariff on US tobacco abolished to open foreign markets. With the rise of the anti-tobacco movement following the 1964 surgeon general's report, tobacco consumption per capita in the US declined steadily. ${ }^{12-17}$ The US tobacco industry, which needed to seek new markets for its future business, targeted the Asian market after exploring Latin America in the $1960 \mathrm{~s}^{16}{ }^{18}{ }^{19} \mathrm{Japan}$, potentially a lucrative market for US tobacco companies, was targeted as the entry point to the Asian market. ${ }^{16}$ During this period, the US government faced a serious trade imbalance, especially with Japan. ${ }^{20}$ Against this backdrop, the US government cooperated with the US Cigarette Export Association (USCEA), (representing Philip Morris, RJ Reynolds, and Brown and Williams, and a subsidiary of British America Tobacco), which pressured the Japanese government via the US Trade Representative to remove impediments to US tobacco exports. ${ }^{12} 16-18$

Tobacco, in fact, was one of the symbolic products that generated trade disputes between Japan and the US, in the same way as beef and oranges have done. In Japan, major newspapers often carried "tobacco" in their headlines of their coverage of negotiations with the US Trade Representative and used the issue to exemplify the bullying tactics of the US government. On the other hand, in the US, tobacco was one of the symbols used to illustrate the closed nature of the Japanese market; the US media rarely carried articles that questioned the government's attempts to open the Japanese market. At that point tobacco trade was addressed solely as an economic and political issue, not as a health issue.

The volume of US tobacco exported to Japan increased from the end of the 1970s and significantly expanded in the 1980s because of the US government's sustained effort to open the Japanese market; however, the market share of foreign cigarettes in Japan was still small: $3.9 \%$ in $1986 .{ }^{21}$ The USCEA, frustrated with the slow expansion of sales in Japan, continued to criticise what it perceived as Japan's unfair tobacco trading practices. The US government, concerned with its accumulating trade deficit, agreed with the USCEA and included tobacco on the list of products facing investigation as subject to possible unfair trade practices under section 301 of the 1974 Trade Act. Facing the threat of trade sanctions, the Japanese government finally abolished the tariff on US tobacco in April 1987. ${ }^{10} 121718$ 22-24 Subsequently, prices of American tobacco were lowered dramatically to compete with Japanese domestic cigarettes, ${ }^{10}{ }^{17}$ and US companies significantly increased advertising and

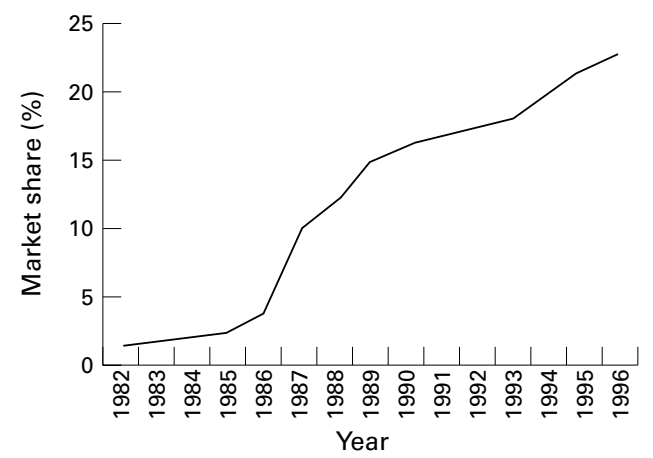

Figure 1 Market share: imported cigarettes as percentage of all cigarettes sold in fapan 1982 to 1996.

promotion activities, which had been already allowed with few restrictions in Japan (table 1)..$^{121618}$

\section{Effects of market liberalisation on US tobacco industry}

US cigarette exports increased significantly in 1987, reversing a gradual decline in the early 1980 s. $^{25}{ }^{26}$ Japan became the leading country to which US cigarettes were exported. As a proportion of total US exports, US cigarettes exported to Japan increased from $16 \%$ in 1986 to $32 \%$ in $1987 .{ }^{27}$ The volume and sales of imported cigarettes in Japan in 1987 were approximately 2.5 times those in 1986: 11.9 billion pieces and 165.7 billion yen in 1986, compared with 30.3 billion pieces and 368.0 billion yen in $1987 .{ }^{28}$ Ninety four per cent of cigarettes imported into Japan in 1987 were US products. ${ }^{27}$ Imported cigarettes as a percentage of all cigarettes sold in Japan also increased precipitately, from $3.9 \%$ in $1986^{21}$ to $9.8 \%$ in 1987 , and reached $22.3 \%$ by $1996^{1}$ (fig 1).

Three major reforms operated the Japanese market: lowering prices by abolishing the tariff, expanding sales networks, and eliminating restrictions on advertising and promotion. ${ }^{12}$ The high tariff $(90 \%)$ was regarded as one of the most significant obstacles preventing US cigarettes from penetrating the Japanese market. The average price of a pack of imported cigarettes in Japan was 100 yen higher than that of domestic cigarettes in 1980 owing to this high tariff and an ad valorem sales tax-for example, a pack of Lark cigarettes cost 290 yen, while a pack of Mild Seven cost 180 yen. ${ }^{29}{ }^{30}$ Responding to intense pressure from the US government, the Japanese government reduced the tariff on imported cigarettes from $90 \%$ to $20 \%$ by 1982 . Despite this dramatic decrease, the price difference between domestic products and imported products did not shrink significantly because the Japanese government introduced an ad valorem tax, in part to prevent dumping. The US government finally urged the Japanese government to lift its tariff, which Japan did in 1987. These reforms allowed the price of American cigarettes sold in Japan to decline by $11 \%$ to $21 \%,{ }^{27}$ narrowing the difference between domestic brands to around 30 yen.

An expansion of the sales network for US cigarettes also played a significant part in 
increasing their market share. The Japanese government held a monopoly on tobacco sales and distribution until 1985. A system of licensed tobacco retail shops limited the number of shops that could offer foreign tobacco products. Although the Japanese government still maintained the license system, it gradually increased the number of licensed shops from 15000 in 1980 to all shops (260 000) in $1985 . .^{6132}$ In addition, since the monopoly on sales and distribution ended when JPMC was privatised to form JT, foreign tobacco companies were free to establish their own sales networks, and to set prices with governmental approval. ${ }^{510}$ In fact, US tobacco companies contracted with Japanese trading companies to create new sales networks. ${ }^{33}$ For their part, the Japanese government continued to hold a monopoly on tobacco production in exchange for abolishing the tariff, as agreed during negotiations with the US Trade Representative in $1986 .{ }^{22}$

The final element in the opening of the Japanese market was Japan's elimination of its restrictions on advertising and promotion on tobacco products. The issue of advertising and promotion never came up in the trade negotiations of $1986,{ }^{12}{ }^{34}$ because the US tobacco industry had already succeeded in eliminating such restrictions before the negotiations. Japanese tobacco industry had adopted a voluntary code based on a budgetary ratio concept in advertising, in which the volume of advertising was determined based on sales in the previous year. Since the market share of US tobacco products in Japan was small, US tobacco companies were restricted in the amount they could spend on advertising. The US Trade Representative argued that US tobacco companies were discriminated against in terms of volume of advertising and succeeded in abolishing the budgetary ratio concept in advertising in 1985 in favour of restriction in the total volume of radio, television, and print advertising. ${ }^{35}$ Consequently, the US tobacco industry was free to increase significantly its advertising volume and expand its promotional activities. The volume of television advertising by US tobacco companies jumped in 1985 and continued to soar until 1990, when time of day restrictions were introduced. ${ }^{36}$ The Japanese government did not formally regulate tobacco advertising except for prohibiting advertising targeted to minors and requiring warning labels. It basically abrogated the responsibility to control advertising to the Tobacco Institute of Japan (TIOJ), established by tobacco companies doing business in Japan. Although the US tobacco companies and members of TIOJ had to abide by the voluntary code, the code was so loose that US tobacco companies had no difficulty in penetrating the Japanese market $^{35}$ (table 1).

\section{Effects on cigarette smoking in Japan}

The Japanese smoking rate among adults reached its peak in the 1960 s $(47.1 \%$ in 1965) and gradually decreased to $34.6 \%$ by $1997 .{ }^{47}$ This decline, however, mainly reflects the male smoking rate, which decreased from $83.2 \%$ in

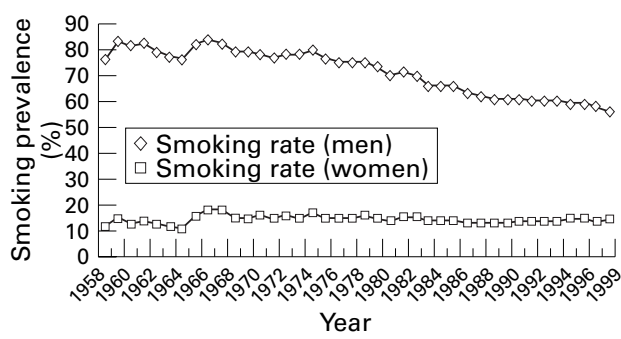

Figure 2 Prevalence of smoking among adults aged 20 years and older in Japan 1958 to 1997.

1965 to $57.5 \%$ in 1997 , while the women's rate stayed approximately the same- $15.7 \%$ in 1965 and $14.5 \%$ in 1997, according to data from JT (fig 2). ${ }^{43} 38$

The overall smoking rate declined steadily from the 1960s to the end of the 1980s. However, the decline was stalled upon market liberalisation. ${ }^{47}{ }^{38}$ In men, the smoking rate continued to decrease, but more slowly than before. Although smoking rates among males in all age groups have shown a significant decrease, the rates among younger age groups decreased more slowly than older age groups. Although the smoking rate among women is still relatively low, the trend has been clearly rising since the end of the 1980s following a declining trend in the early 1980s: $14.4 \%$ in $1980,13.7 \%$ in $1985,14.3 \%$ in 1990 , and $15.2 \%$ in $1995 .{ }^{4738}$ Furthermore, there has been a striking increase in the smoking rates among younger female age groups and a significant stagnation in previously declining rates among middle age groups since the end of the 1980 s (fig 3). ${ }^{48}$ There is a significant difference in the slopes of smoking prevalence trends before and after market liberalisation in all age groups except women aged 60 years and over (table 2). The timing of these trends is plausibly linked to the aggressive sales campaign targeting women by US tobacco companies since the opening of the Japanese market. The stagnation in overall smoking prevalence, the stalling of a declining trend among younger men, and the increasing trend of smoking prevalence among younger women all happened during and since the period of market liberalisation.

The smoking rate among Japanese adolescents also appears to have increased sharply in recent years, although we are unable to attribute this increase to market liberalisation because of lack of reliable data on adolescent smoking behaviour before market liberalisation. Smoking prevalence data collected by both JPMC (later JT) and the Ministry of Health and Welfare (MHW) were restricted to people 20 years and older on the ground that the law forbade smoking among people under 20 years. ${ }^{4}$ Consequently little research has been done in Japan to document the patterns of adolescent smoking behaviour. ${ }^{47}$ The available data, however, suggested that smoking rates among adolescents increased after market liberalisation. The Japan Know Your Body (JKYB) project conducted a baseline survey of smoking among adolescents in 1989. Researchers reported that $37 \%$ of 


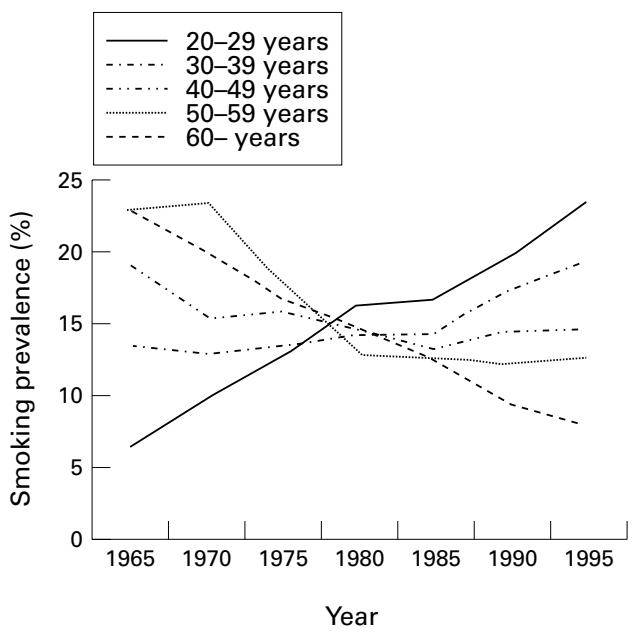

Figure 3 Prevalence of smoking among women by age group in Japan 1965 to 1995.

male 12 th graders and $15 \%$ of female 12 th graders (ages 17-18 years) were monthly smokers, and $34 \%$ of male 12 th graders and $12 \%$ of female 12 th graders were weekly smokers. The proportion of students who reported ever smoking was $66 \%$ among male 12 th graders and $42 \%$ among female 12 th graders. $^{39}$ Two years later, according to the first national survey conducted by Osaki and Minowa in $1991,{ }^{40} 4120.3 \%$ of male 12 th graders and $2.6 \%$ of female 12 th graders were regular smokers, while $25.5 \%$ of male 12 th graders and $4.9 \%$ of female 12 th graders were monthly smokers. Research conducted in 1995 similarly indicated a rising prevalence of smoking among adolescents; $25.4 \%$ of male 12 th graders and $7.1 \%$ of female 12 th graders were regular smokers, while $36.9 \%$ of male 12 th graders and $15.6 \%$ of female 12 th graders reported having smoked in the previous month. The proportion reporting ever smoking was $55.6 \%$ among male 12 th graders and $38.5 \%$ among female 12 th graders. ${ }^{42}$

Because these studies adopted different sampling methods and different definitions of smoking status, their results cannot be directly compared. However, all of them indicate that smoking rates among minors are high.

Few studies have been conducted on smoking behaviour among elementary students. One study by JKYB showed that there was no significant difference in the proportion of children who had ever smoked from grade 1 (ages 6-7 years) to grade 5 (ages 10-11) among male students $(8 \%, 11 \%, 16 \%, 14 \%$, and $13 \%$ ), but there was a significant difference among grade 6 students (ages 11-12 years) $(22 \%)$. There was also no significant difference in female students between grades 1 and $6(4 \%, 6 \%, 5 \%, 7 \%, 5 \%$, and $9 \%){ }^{39}$

Table 2 Changes in trend of female smoking prevalence before and after market liberalisation

\begin{tabular}{lll}
\hline Age group (years) & 1965 to 1985 slope (95\% CI) & 1985 to 1995 slope (95\% CI) \\
\hline $20-29$ & $2.64(2.33$ to 2.95$)$ & $3.35(3.09$ to 3.61$)$ \\
$30-39$ & $0.26(0.15$ to 0.37$)$ & $2.55(2.29$ to 2.81$)$ \\
$40-49$ & $-1.33(-1.54$ to -1.12$)$ & $0.45(0.25$ to 0.65$)$ \\
$50-59$ & $-3.13(-3.74$ to -2.52$)$ & $0(-0.23$ to 0.23$)$ \\
$60+$ & $-2.66(-2.80$ to -2.52$)$ & $-2.25(-2.68$ to -1.82$)$ \\
\hline
\end{tabular}



Figure 4 Volume of cigarette sales in Fapan 1982 to 1996.

Effects on the tobacco industry in Japan

The total number of cigarettes sold in Japan has increased continually since the beginning of this century, except during the second world war: 20.9 billion in 1920, 65.2 billion in 1950, 303 billion in 1980, and 334.7 billion in 1995. ${ }^{43}$ However, recent data suggest that there is a significant connection between the total number of cigarettes sold and market liberalisation. The total number of cigarettes sold decreased each year from 1982 to 1987 , then it started to increase after the 1987 opening of the market: 310 billion in 1982, 308 billion in 1987, and 314 billion in $1989 .{ }^{43}$ Cigarette consumption, measured by volume of tobacco purchased (rather than by number of cigarettes) decreased by $1 \%$ from 1985 to 1988 , but increased by $3.6 \%$ from 1988 to 1990. ${ }^{4}$ Chaploupka and Laixuthai examined the effect of market liberalisation on per capita cigarette consumption in several Asian countries including Japan. They estimated that cigarette consumption per capita in 1991 was approximately $10 \%$ higher than that in the case of a closed market ${ }^{44}$.

Domestic sales of cigarettes by JT dropped significantly in 1987, while sales by foreign tobacco companies increased (fig 4). Although JT steadily lost market share to foreign competition, JT cigarette sales by volume remained stable. Total cigarette consumption in Japan thus increased as a result of market liberalisation, ${ }^{43}$ reversing the gradual decreasing trend in total cigarette sales in Japan before 1987. In response to the threat of competition from foreign cigarettes, JT introduced seven new brands in $1987,{ }^{10}$ which seemed to target mainly the young population, especially women and adolescents. JT also increased the volume and sophistication of its advertising and promotional activities. ${ }^{14}$

Various ordinances, regulations, and voluntary codes have regulated the advertising and promotion activities of the tobacco industry in Japan. $^{34}$ Although there was no formal regulation of advertising in the mass media, the volume of tobacco advertisements was controlled by moral suasion before market liberalisation. Because JPMC was directly (and JT indirectly) supervised by the Ministry of Finance (MOF), and the Japanese tobacco industry enjoyed its monopoly with full MOF support, an informal agreement existed with the government not to advertise heavily on TV and not to target young women and 
adolescents. ${ }^{16}$ However, heavy advertising and promotional activities began when the US Trade Representative succeeded in convincing the Japanese government to ease advertising restrictions. ${ }^{1634}$ The US cigarette companies took advantage of the fact that Japan had some of the loosest advertising restrictions in the world; the three US tobacco companies, Philip Morris, RJ Reynolds, and B \& W, spent two thirds of their advertising budget and almost half of their promotional budget intended for the Asian market on Japan alone in 1990. They doubled their total expenditures for advertising and promotional activities in Japan from 1987 to $1990 .^{34}$

The three US cigarette companies relied heavily on television advertising, which has been prohibited in the US since 1974. The volume of both television spot advertising and television programme advertising by US cigarette companies increased dramatically. ${ }^{18} 196$ Following suit, JT also increased its expenditures on TV advertising, and the total volume of TV advertising jumped until 1989, when time restrictions were introduced (fig 5A, B). Advertising in magazines has also showed a significant increase (fig 5C). The volume of advertising in magazines by foreign tobacco companies increased steeply in 1989 and has remained high.

Changes in the voluntary codes not only expanded the opportunities for marketing of foreign cigarettes but also eliminated the cap that controlled cigarette advertising in Japan. Both JT and US tobacco companies increased their total volume of advertising. The lax control of advertising, which worked well during the era of government monopoly, became a major public health threat under competition. Consequently, Japanese people were exposed to far more advertisements on television and in magazines than ever before. ${ }^{18} 19$

A further consideration related to increased advertising and promotional activities is their effect on adolescents and young women, whom the tobacco industry claims not to have targeted. The Tobacco Enterprise Law of 1984 called for the tobacco industry to consider the effect of advertising on minors; however, the statement was vague and the law included no concrete guidelines and no sanctions. TIOJ adopted self regulatory codes of restrictions on targeting minors and females in $1985 .{ }^{43}$ However, considering the significant influence of advertising and promotion on smoking behaviour among females and young people, ${ }^{45} 46$ it is plausible that the aggressive advertising and promotional activities by the tobacco industry produced the increase in smoking prevalence in these groups.

Few studies have been carried out on the effect of cigarette advertising in Japan. While we have no conclusive studies regarding the effect of cigarette advertising on adolescents and females, studies have documented young women's awareness of tobacco advertising in various media. ${ }^{47}$ According to Sone, more than $95 \%$ of Japanese nursing students were aware of television advertisements (99\%) and billboard advertisements $(96.4 \%)$ for ciga-
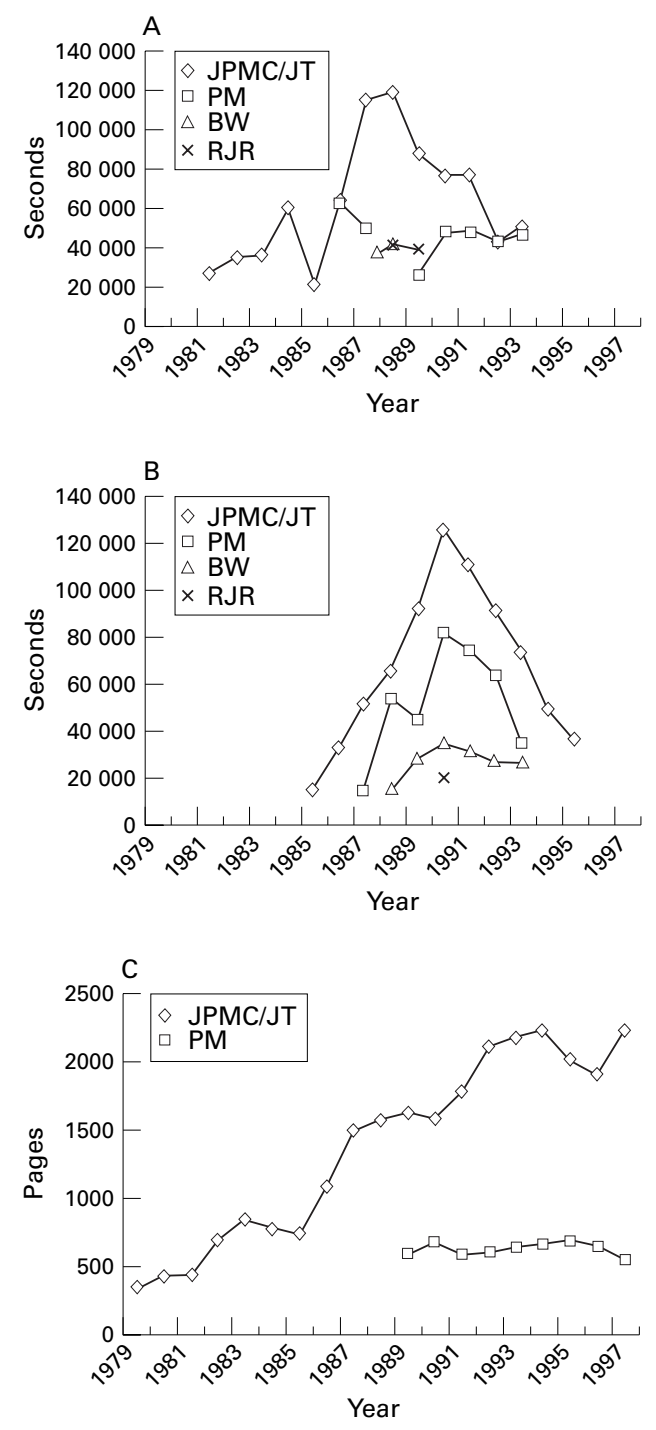

Figure 5 Television spot advertisements $(A)$, television programme advertisements (B), and magazine advertisements (C) for cigarettes in Fapan 1979 to 1997.

rettes. More than $50 \%$ of the respondents who had smoking experience perceived that they were frequently exposed to television/billboard advertisements, compared with $50 \%$ of never smoking respondents who perceived that they were only occasionally exposed to advertisements. ${ }^{47}$ One of the few studies on smoking among young people showed that both male and female university students were more likely than the general population to choose American brands. Half of the brands ranked among the top 10 preferred brands by university students were American brands, whereas only one American brand ranked among the top 10 brands with respect to market shares in $1992 .^{48}$ Another recent study by Hagihara and Takeshita presented empirical evidence of the impact of advertisements by US cigarette companies on the market share of imported cigarettes in Osaka, Japan during the period 1970 to 1990 . They concluded that televised commercials by US cigarette companies encouraged brand switching from domestic cigarettes to US brands during this period. ${ }^{49}$ 


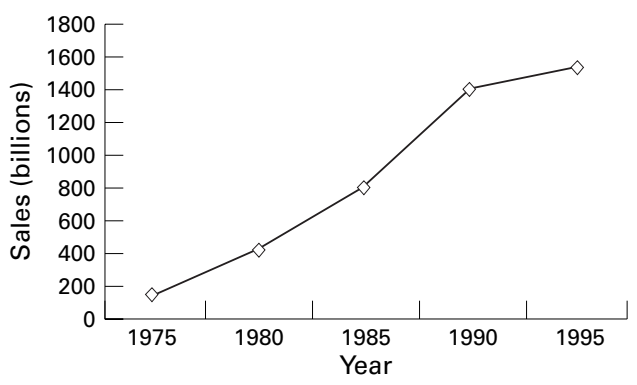

Figure 6 Sales of cigarettes by vending machine in fapan 1975 to 1995.

The ubiquitousness of cigarette vending machines is another significant factor contributing to high smoking rates among minors in Japan. The use of vending machines in Japan was accelerated by market liberalisation. Both the total sales by vending machines and the number of vending machines have increased over the last few decades. Total sales of cigarettes through vending machines were 800 billion yen in 1985, 1406 billion yen in 1990, and 1530 billion yen in 1995 . Cigarette sales by vending machine accounted for $40 \%$ of total sales of cigarettes in Japan in 1995. There were 369900 cigarette vending machines in Japan in 1985, 443460 in 1990, and 498800 in 1995 . Total cigarette sales by vending machines increased significantly during the latter half of the 1980s; total sales approximately doubled between 1985 and 1990 (fig 6). ${ }^{38} 43$

Vending machines are a serious problem in terms of smoking control among minors. Recent studies reported that more than $70 \%$ of adolescents who smoke obtain cigarettes from vending machines. ${ }^{41450}$ Vending machines allow adolescents easier access to cigarettes than do retail shops. ${ }^{51}$ Because of the significant influence of vending machines on adolescents' smoking behaviour, the Japan Tobacco Retail Association was pressured in 1995 to adjust the 350000 outdoor vending machines so they would not operate between $11 \mathrm{pm}$ and $5 \mathrm{am} .{ }^{52}$ However, only $20 \%$ of adolescent smokers buy cigarettes during that time period, ${ }^{43}$ so it is doubtful the regulation is effective.

\section{Effects on smoking control in Japan}

An unexpected side effect of market liberalisation is on the coalescence of an organised tobacco control movement in Japan.

In the 1980s, the mass media carried far more news regarding smoking and health than ever. The number of anti-tobacco newspaper articles sharply increased around 1987, when market liberalisation was debated in the Parliamentary Diet. More politicians brought the health and smoking issues to the Diet and pointed out the possible effects of market liberalisation such as increased advertising and promotional activities. They also expressed concern over the influence of increased advertising and promotional activities on adolescent smoking behaviour. The sixth World Conference of Smoking and Health, held in Tokyo in 1988, also captured the media's attention. Newspapers often covered scientific information regarding the health effects of smoking and smoking control in other countries such as the UK and the US. Many newspapers conducted surveys about cigarette smoking.

Anti-tobacco activities by non-governmental organisations (NGOs), first visible in the 1970 s, became more prominent in the 1980s. The sixth World Conference of Smoking and Health in 1988 was a landmark NGO activity in Japan. As the severity of health problems caused by smoking was emphasised publicly through the media, anti-tobacco groups expanded their power to mobilise social interests. Japanese people began to see the threat to their future that market liberalisation might pose; the scientific evidence carried by the media legitimised the anti-tobacco activities of various organisations and citizen groups.

The effects of market liberalisation could also be seen within the Japanese government. The Ministry of Health and Welfare (MHW) supported by the media and citizen groups, began to take a more active stance towards tobacco control. The MHW published a White Paper on smoking and health on October 16, 1987 (revised in 1993), the first ever comprehensive government sponsored review of scientific findings. ${ }^{47}$ The MHW also supported the NGOs in convening the sixth World Conference of Smoking and Health. With the increase in smoking rates among young women and adolescents beginning in 1987, the MHW became more concerned with the aggressive marketing by US tobacco companies. In 1994, it established the Tobacco Control Committee, with members invited from various sectors and organisations including JT and TIOJ. The committee generated recommendations for future smoking control actions. $^{37}$

The MOF was inactive until the end of the 1980s, maintaining the position that smoking was a matter of individual choice. In 1984, the MOF promulgated the Tobacco Enterprise Law with the privatisation of the JPMC. Its provisions were the same as those previously promulgated by the Tobacco Monopoly Law (1886); it forbade sales and promotion of tobacco to people younger than 20 years old and required the tobacco industry to put stricter warning labels on each packet of cigarettes such as "Do not smoke too much for fear of damaging your health". The MOF, also concerned about the significant influence of aggressive marketing by US tobacco companies, devised the guidelines for advertising of tobacco products in order to prevent smoking by minors and to publicise the relation between tobacco consumption and ill-health. These guidelines gave the MOF authority to make recommendations regarding "excessive" advertisement and promotion. However, there is little evidence that these vague guidelines, which were not backed by sanctions, were effective.

Other ministries also began to express concern about the tobacco issue. The Ministry of Education, seriously concerned about 
adolescents' smoking behaviour, directed that smoking education be included as part of school curricula in the early 1990s. The Ministry of Labor, concerned about environmental tobacco smoke in the workplace, announced guidelines in 1992 for employers to take measures to promote smoke-free or partially smokefree work environments. ${ }^{43}{ }^{5}$ The Imperial Household Agency, responding to frequent requests by citizen groups, stopped using cigarettes as imperial gifts, a practice that had dated back to $1877 .^{54} 55$ The Ministry of Transportation permitted taxi drivers to restrict smoking in their taxicabs. ${ }^{54}$ Thus, in the past decade, the Japanese government, threatened by the serious health effects of smoking and increasing smoking among young people and women, has paid more attention to smoking issues than ever before.

In the meantime, non-smoking was promoted in public places by private and public companies in response to consumer demand. Japan Railways increased the proportion of non-smoking seats, from $0 \%$ of all super express and express trains in 1980 to $40 \%$ in $1992 .{ }^{56}$ Many other forms of public transport introduced total or partial bans on smoking in stations; smoking was banned in all subway stations in Tokyo in $1988 .{ }^{4}$ The proportion of non-smoking seats on domestic flights increased from $36 \%$ in 1982 to $50 \%$ in $1988 .^{57}{ }^{58}$ Japan AirLines banned smoking on all domestic flights of less than two hours' duration in $1990 .{ }^{43}$ Some municipal governments introduced separation of smokers in their office buildings. ${ }^{43}$

Under growing social pressure, the tobacco industry gradually strengthened its voluntary regulatory code. In 1985, TIOJ established voluntary codes and restricted tobacco advertising on television between $6 \mathrm{pm}$ and 9 $\mathrm{pm}$. The voluntary codes were gradually tightened until, in 1991, they banned television advertisements between 5 am and $1054 \mathrm{pm}$. on weekdays, and reduced the number of advertisements on radio. In 1995, TIOJ reduced television advertisements by an additional $28.6 \%$ and radio advertisements by an additional $25.9 \%$, eliminated television and radio tobacco advertisements on weekends (fig 5), and agreed to remove billboards within a $100 \mathrm{~m}$ radius of schools by 1998, as recommended by the Tobacco Control Committee. $^{59}$

In 1997, the MHW stated for the first time in its White Paper that smoking is a health issue. ${ }^{60}$ It established a new tobacco committee, and held a series of meetings to discuss future smoking control measures in 1998. TIOJ finally removed all tobacco advertisements on television and radio in April 1998, and prohibited distribution of free tobacco samples, which until then had been allowed anywhere in Japan except near schools. ${ }^{61}$ Recently, life insurance companies began discounts for non-smokers, and all three domestic airlines banned smoking on all commercial passenger flights.

In summary, an unintended consequence of market liberalisation in Japan has been the strengthening of tobacco control measures during the last two decades. During the same period, smoking in Japan has been gradually transformed from a matter of individual choice to a public health issue.

1 Japan Tobacco. 1997-nen Zenkoku tabako-kitsuensyaritsucyosa: Danjo-kei de 34.6\% [1997 National Cigarette smoking prevalence survey: Prevalence is $34.6 \%$ ]. Press release. No 21, November 27, 1997

2 World Health Organization. Tobacco or health: a global status report. Geneva: WHO, 1997.

3 Wynder E, Fujita Y, Harris RE, Hirayama T, Hirayama T. Comparative epidemiology of cancer between the United States and Japan: a second look. Cancer 1991;67:746-63.

4 Ministry of Health and Welfare (Japan). Kitusen to Kenko [smoking and health]. 2nd ed. Tokyo: Hokendojinsya, 1993.

5 Asahi Shimbun. Tabako-senbai haishi. 1984 April 3, 4(2).

5 Asahi Shimbun. Tabako-senbai haishi. 1984 April 3, 4(2).

7 Asahi Shimbun. Big ga gappuri 4tsu-tabako-jiyuuka. 1984 August 4, 14 (23)

8 Asahi Shimbun. Tabako-masatsu. 1984 August 22, 12 (11).

9 Asahi Shimbun, April 1, 1985.

10 Hadfiel P. The new Marlboro man: American tobacco in the saddle. The fournal 1992; January:10-16.

11 Asahi Shimbun., Tabako no mineika. 1981 September 14, 1

12 General Accounting Office (US). Trade and Health Issues. Washington, DC: GAO, 1990. (GAO Publication No: NSLAD-90-190.)

13 Mackenzie TD, Bartecchi CE, Schrier RW. The human cost of tobacco use (second of two part). N Engl $f$ Med 1994;330:975-80.

14 Department of Agriculture (US). Situation and outlook report: tobacco. Washington, DC: Economic Research Service, 1992. Report TS-220.

15 Centers for Disease Control and Prevention. Cigarette smoking in the United States, 1986. MMWR Morbid Mortal Wkly Rep 1987;36:581-5.

16 Heise L. Unhealthy alliance: with US government help, tobacco firms push their goods overseas. Worldwatch 1988; September and October:19-28.

17 Council on Scientific Affairs. The worldwide smoking epidemic: tobacco trade, use, and control. $\mathcal{F A M A} 1990$; 263:3312-8.

18 Connolly GN. Worldwide expansion of transnational tobacco industry. F Natl Cancer Inst Monographs 1992; 12:29-35.

19 Barry M. The influence of the US tobacco industry on the health, economy, and environment of developing counhealth, economy, and environment of
tries. N Engl f Med 1991;324:917-20.

20 JETRO. White paper of JETRO: Sekai to Nihon no Boeki [Trading between Japan and other countries]. Tokyo: JETRO, 1989.

21 Tobacco Institute of Japan. 1986 Tobacco hanbai jisseki nituite [1986 Sales of tobacco in Japan]. Tokyo: TIOJ, 1987, April 24.

22 Asahi Shimbun, Kanzei 30\% hikisage-tabako ha zero no. 1986 December 25, 14 (9)

23 Asahi Shimbun, 4gatsu kara kanzei zero. 1986 October 4, 4 (1).

24 Mackey J. US tobacco export to third world: third world war. $\mathcal{F}$ Natl Cancer Inst Monographs 1992;12:25-8.

25 Asahi Shimbun, Tabako-kanzei teppai he. 1986 October, 4, $14(1)$

26 General Accounting Office (US). International trade: advertising and promoting US cigarettes in selected Asian countries. Washington DC: GAO,1992. (GAO Pubication No. GGD-93-38.)

27 Department of Agriculture (US). Tobacco: situation outlook report. Washington, DC: Economic Research Service, 1988. Report TS-203.

28 Tobacco Institute of Japan. 1987 Tobacco hanbai jisseki nituite (1986 Sales of tobacco in Japan). Tokyo: TIOJ, 1988 April 25.

29 Asahi Shimbun. Tabako neage seiritsu. 1980 March 31, 3 (1).

30 Asahi Shimbun, "tabako-banare" ni hakusya? 1980 March 31, $3(10)$.

31 Asahi Shimbun, Yunyu-tabako mo neage. 1980 April 16, 13 (13)

32 Asahi Shimbun, Gaikoku-tabako neage. 1981, April 14, 13 (3).

33 Asahi Shimbun, Gyousya baizoushi, kyousou honkakuka. 1985 July $14,14(9)$.

34 General Accounting Office (US). International trade: advertising and promoting US cigarettes in selected Asian countries. Washington DC: GAO, 1992. (GAO Publication No. GGD-93-38.)

35 Sato H. Politics of smoking control in Japan [dissertation] Cambridge (MA): Harvard University, 1997.

6 Nikkei-koukoku-kenkyujyo. Kokoku-hakusyo. Tokyo: Nikkei-kokoku-kenkyujo, 1980-1998.

37 Health Welfare Statistics Association. Kokumin-eisei no doko: Kosei no shihyo. Tokyo: HWSA,1996, Publication No.43 (9):99-100.

38 Japan Tobacco. 1997 Kaisha gaikyo (Outlook report). Tokyo: JT, 1997. 
39 Kawabata T, Nakamura M, Oshima A, et al. Smoking and alcohol drinking behavior among Japanese adolescents: results from the "Japan Know Your Body Study". Nippon Koshu Eisei gakkai-zasshi [Fapanese fournal of Public Health] 1991:38:885-99.

40 Osaki Y, Minowa M. Nationwide survey of smoking prevalence among school students in Japan. Nippon Kosyu-eise gakkai-zasshi [Fapanese fournal of Public Health] 1993; 40:39-47.

41 Osaki Y, Minowa M. Cigarette smoking among junior and senior high school students in Japan. Fournal of Adolesc Health 1996;18:59-65.

42 Minowa M, Suzuki K, Wada K, Osaki Y. Miseinen no kitsuen-kodo ni kansuru zenkoku cyousa hokokusho [Report of nationwide survey of smoking prevalence among minors]. Heisei 9 nendo kousei-kagaku-kenkyuhi-hojokinkenkouzoushin-kenkyu-jigyou: "bouen no jittai ni kansuru kenkouzoushin-kenkyu-jigy
kenkyu" han. 1998 March.

43 Kenko Tairyokuzukuri Jigyozaidan. Tabako to knenko [Tobacco and Health]. Available from: http://health[Tobacco and Health]. Available from: htt.

44 Chaloupka FJ, Laixuthai A. US trade policy and cigarette smoking in Asia. National Bureau of Economic Research smoking in Asia. National Bureau of Econom

45 Royal College of Physicians of London. Smoking and the young. A report of a working party of Royal College of Physicians. London: Royal College of Physicians of London, 1992: 55-74.

46 US Department of Health and Human Services. Reducing the health consequences of smoking: 25 years of progress. A report of the Surgeon General, 1989. Rockville, Maryland: Public Health Service, Centers for Disease Control, Office on Smoking and Health, 1989. (DHHS Publication No (CDC) 89-8411.)
47 Sone T. Frequency of contact with cigarette advertising and smoking experience among young women in Japan. $\mathcal{F}$ Epidemiol 1997;7:44-7.

48 Osaki Y, Minowa M. Cigarette brand preferences of smokers among university students, Japan. Final program, 4th Asia-Pacific Conference on Tobacco or Health, 1995, p84.

49 Hagihara, A, Takeshita, Y J. Impact of American cigarette advertising on imported cigarette consumption in Osaka, Japan. Tobacco Control 1995;4:239-44.

50 Asahi Shimbun. Kantandakara to jihannki riyou. 1995 July $16,14(1)$.

51 Shiramizu M, Hiroshita T, Shibata A. Kokosei no kitsuen-ishi to sono kanren-yoin. Nihon Eisei zasshi [Fapanese fournal of Hygiene] 1986;40:589-96.

52 Nikkei Shimbun, Tabako-jihannki shinyah-hanbai teishi. 1996 January 10

53 Mochizuki KY. Kokunaigai no tabakotaisaku no genkyo. Rinsyokagaku 1998;34:186-94.

54 Asahi Shimbun, 1993 March 3.

55 Mainich Shimbun, 1988 February 8.

56 Isayama Y. Kenen-ken wo kangaeru. Tokyo: Iwanami-syoten, 1983.

57 Asahi Shimbun, 1994 November 1.

58 Mainichi Shimbun, 1988 April 22

59 Asahi Shimbun, Tabako no CM do-nichi yamemasu. 1995 June 20.

60 Ministry of Health Welfare (Japan). Kosei-hakusho [White Paper on health and welfare]. Tokyo: Gyosei, 1997.

61 Yomiuri Shimbun, 1997 September 7. 